ISSN 1112-9867

Available online at $\quad$ http://www.jfas.info

\title{
THE ASSESSMENT OF PSYCHOMOTOR DOMAIN AMONG RESERVE OFFICERS TRAINING TEAM (PALAPES)
}

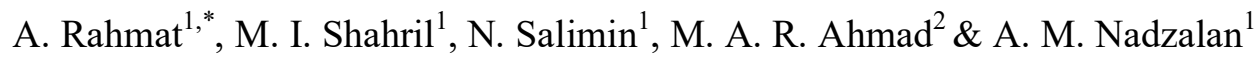 \\ ${ }^{1}$ Faculty of Sports Science and Coaching, Universiti Pendidikan Sultan Idris, Tg Malim, \\ Perak, Malaysia \\ ${ }^{2}$ Faculty of Management and Economics, Universiti Pendidikan Sultan Idris, Tg Malim, \\ Perak, Malaysia
}

Published online: 10 November 2017

\begin{abstract}
This study was conducted to determine the level of psychomotor domain among Reserve Officers Training Team (PALAPES) after underwent three years of training module. 105 PALAPES cadet officers were recruited as participants in this study. Co-curriculum index assessments (IPKo) were used to assess psychomotor domain achievement level. Results showed all psychomotor skills were rated only at a 'good' and 'moderate' level. The skill item showed the highest percentage of $65.7 \%$ cadets at 'good' level and $34.3 \%$ cadets are at 'moderate' level with mean value of 3.66. The overall mean of psychomotor skills (physical skills) is at a 'good' level of 3.56. Results demonstrate the effectiveness of co-curricular activities involvement among university students in developing psychomotor domains.
\end{abstract} Keywords: co-curricular, psychomotor, training module, PALAPES, IPKo

Author Correspondence, e-mail: azali@fsskj.upsi.edu.my

doi: http://dx.doi.org/10.4314/jfas.v9i6s.103 


\section{INTRODUCTION}

Co-curriculum implementation has now been entrusted to shape the identity of the students so that they will come out as successful and innovative teens [1-3]. In the current globalization, career fields require individuals who are not only knowledgeable, but also have good skills. Workers with good skills can adapt to any work environment and can improve the quality of the company [4-6]. In the era of development towards the 21 st century, society and nation generally demand that Higher Education Institutions (IPTs) produce quality and excellent graduates.

According to Chin Pek Lian et al., [7], co-curriculum can provide many benefits to students. Co-curriculum is a channel that promotes the development of talent and the creativity of students [8]. Knowledge, experience and skills that contain intellectual elements, self-discipline, leadership, entrepreneurship, creativity, innovation, love for nature, citizenship, loyalty to the nation, culture and national integration will help students determine their direction of life in the future [9-10]. A co-curriculum course basically has their own specific goal that are to assist the university to produce skilled, balanced, and harmonious graduates in spiritual, intellectual, emotional, social, and physical aspects in line with the aspiration of the National Education Philosophy [2].

At institute of higher education there are several uniformed forces established for co-curricular activities or activities, in addition to train students to be more disciplined, in accordance with the rules, having a sense of identity and a state of patriotic [11]. To meet the requirements of the Malaysian Armed Forces, apart from producing reserved officers, Reserve Officer Training Team or also known as PALAPES do support the efforts of governments and IPTAs to establish the quality of a perfect, disciplined citizen and have the characteristics of defending the nation's interests [12-13]. PALAPES is a collaborative program between the Ministry of Defense for students at the Public Higher Education Institution (IPTA). A cadet officer will be trained within 3 years of 6 semesters on a part-time basis where regular training covering military-related subjects will be held every weekend. The PALAPES program now includes all branches of services in ATM namely PALAPES Army, Navy and Air Force. 
After three years involved in PALAPES training, it is important to know whether the students have occupy the skills or domain that are important for job market. Among the domain that needs to be acquired by the students is the psychomotor. This study aimed to examine the level of psychomotor domain among the PALAPES student in UPSI. The Assessment Index detects all the psychomotor skills the students underwent during the co-curricular course. The results of this index are of great importance to show the level of functionality of the student that involved in PALAPES for the job market.

\section{METHODOLOGY}

\subsection{Participants}

In this study, researchers have selected PALAPES cadet officers who are in semester six (6) as the sample of the study as they have went through all the modules provided by the Ministry of Defence. There were 105 PALAPES cadet officers selected as samples in this study. They have been trained for three (3) years of military training for young staff.

\subsection{Instrument}

Co-curriculum index assessments (IPKo) was used to assess psychomotor domain achievement level. Table 1 showed the item in the psychomotor domain in the IPKo. 
Table 1. Psychomotor Assessment Items

Psychomotor Assessment Item (Physical Skills)

1. Marching

2. Weapon marching

3. Weapon control

4. Weapon care

5. Battlefield knowledge

6. Tactical

7. Maps understanding

8. Fitness

9. Step forward

10. Attack

11. Defense

12. Retreat

The criteria used in the Co-curriculum Assessment Index (IPKo) for assessing cadet's psychomotor domain are the percentage achievement level. The level of psychomotor domain achievement of student achievement is determined based on scale such as in Table 2.

Table 2. Level of Achievement

\begin{tabular}{cc}
\hline Achievement Level & Criteria Level \\
\hline 5 & Excellent \\
4 & Good \\
3 & Moderate \\
2 & Weak \\
1 & Very Weak \\
\hline
\end{tabular}




\subsection{Data collection}

A total of eleven (11) coaches from among the officers and members of the lower rank forces have been appointed to assess and implement the instruments. All the participants were assessed in their psychomotor domains developed during the co-curricular course.

\subsection{Statistical analysis}

Descriptive statistics were used to obtain participants physical characteristics and mean score. Independent t-test was used to compare the mean score between male and female in the PALAPES unit. All statistical analysis were done by using Statistical Package for the Social Science (SPSS) software, version 23 (IBM, USA).

\section{RESULTS AND DISCUSSION}

This study was conducted on the PALAPES unit in Universiti Pendidikan Sultan Idris which represents the whole unit of uniform in the co-curriculum course. Here's a detail of the demographic background for this study. Table 3 showed the percentage distribution of students by gender. A total of 43 (41\%) male cadet and $62(59 \%)$ female cadet were involved in this study.

Table 3. Percentage distribution of cadets by gender and program followed

\begin{tabular}{lll}
\hline Gender & $\mathrm{N}$ & $(\%)$ \\
\hline Male & 43 & 41 \\
Female & 62 & 59 \\
\hline
\end{tabular}


Table 4. Cadet Level of Achievement in Psychomotor Domain

\begin{tabular}{llll}
\hline & \multicolumn{2}{l}{ Achievement Level } & \\
Psychomotor Assessment Item (Physical Skills) & Good & Moderate & Mean \\
& $\mathrm{N}(\%)$ & $\mathrm{N}(\%)$ & \\
\hline 1. Marching & $65(61.9 \%)$ & $40(38.1 \%)$ & 3.62 \\
2. Weapon marching & $49(46.7 \%)$ & $56(53.3 \%)$ & 3.47 \\
3. Weapon control & $59(56.2 \%)$ & $46(43.8 \%)$ & 3.56 \\
4. Weapon care & $61(58.1 \%)$ & $44(41.9 \%)$ & 3.58 \\
5. Battlefield knowledge & $61(58.1 \%)$ & $44(41.9 \%)$ & 3.58 \\
6. Tactical & $60(57.1 \%)$ & $45(42.9 \%)$ & 3.57 \\
7. Map reading & $58(55.2 \%)$ & $46(43.8 \%)$ & 3.52 \\
8. Fitness & $63(60.0 \%)$ & $42(40.0 \%)$ & 3.60 \\
9. Step forward & $54(51.4 \%)$ & $51(48.6 \%)$ & 3.51 \\
10. Attack & $46(43.8 \%)$ & $59(56.2 \%)$ & 3.44 \\
11. Defense & $58(55.2 \%)$ & $47(44.8 \%)$ & 3.55 \\
12. Retreat & $69(65.7 \%)$ & $36(34.3 \%)$ & 3.66 \\
$\quad$ Total mean & & & 3.56 \\
\hline
\end{tabular}

Table 4 showed the level of psychomotor domain achievement among the cadets during the assessment. It was found that the cadet psychomotor skills are only at a "good" and "moderate" level. For attack skill items, at least $43.8 \%$ of the cadets are at a "good" level and $56.2 \%$ of the cadets are at "moderate" level with a mean value of 3.44 . While the retirement skill item showed the highest percentage of "good" level that are $65.7 \%$ of all the cadets while $34.3 \%$ cadets are at "moderate" level with mean value of 3.66. The overall mean of psychomotor skills (physical skills) is at a "good" level of 3.56 . 
Table 5. Mean Differences in Cadet Psychomotor Achievement Level using IPKo between Genders

\begin{tabular}{cccccccc}
\hline Sex & N & Mean & SD & F & Sig. & t & df \\
\hline Male & 43 & 3.57 & 0.084 & 0.198 & 0.658 & 0.87 & 103 \\
Female & 62 & 3.55 & 0.070 & & & 0.86 & 8.770 \\
\hline
\end{tabular}

Table 5 showed the difference in the level of psychomotor domain between male and female cadet after following PALAPES training. Analysis showed that the value of $\mathrm{t}(103)=0.87, \mathrm{p}$ $=0.658$ is insignificant. There was no significant differences in mean psychomotor level between male cadet and female cadet $(M=3.55, S D=0.070)$, with male students $(M=3.57$, $\mathrm{SD}=0.084)$. Despite the fact that male cadet score were higher compared to the female cadet, it cannot differentiate the level of achievement in psychomotor domain between these two genders as a result of three years involved in PALAPES training.

\section{CONCLUSION}

The psychomotor domain relates to the learning of physical movements and progresses through the levels of reflex movements, fundamental movements, perceptual abilities, physical abilities, skilled movements and expressive movements [14]. Findings of this study demonstrated the benefits for university students to involve in co-curricular activities such as PALAPES in enhancing their psychomotor domain that was in line with the aspiration of the National Education Philosophy.

\section{ACKNOWLEDGEMENTS}

This study was funded by the Ministry of Education (MOE) under the Fundamental Research Grant Scheme (FRGS) (Research Code: 2014-0104-106-02). 


\section{REFERENCES}

1. Das, D. (2016). Role of co-curricular activities in bringing all-round development to the students of high school stage with specials reference to Guwahati, India: a study. The Clarion, 5(2), 75-81.

2. Rahmat, A., Shahril, M., Ahmad, M. A. R., Ishak, N. A., \& Salimin, N. (2017). The Effectiveness of Implementing Credit Hours Co-Curricular Courses in Sultan Idris Education University. Advanced Science Letters, 23(1), 545-549.

3. Yassin, S., Hasan, F. A., Amin, W., \& Amiruddin, N. (2008). Implementation of generic skills in the curriculum. Proceedings of the EDU-COM 2008 International Conference.

4. Shafie, L. A., \& Nayan, S. (2010). Employability awareness among Malaysian undergraduates. International Journal of Business and Management, 5(8), 119.

5. Stewart, M. (2017). Student Perceptions of Soft Skills as an Indicator of Workplace Success (Doctoral dissertation, Creighton University).

6. Townsend, A. M., DeMarie, S. M., \& Hendrickson, A. R. (1998). Virtual teams: Technology and the workplace of the future. The Academy of Management Executive, 12(3), 17-29.

7. Chin Pek Lian, et al. (2005). Isu-isu masalah disiplin pelajar : pendekatan dan penyelesaian. Seminar pendidikan. Fakulti Pendidikan, Universiti Teknologi Malaysia, 15 Oktober 2005.

8. Rahmat, A., Shahril, M. I., Salimin, N. Ahmad, M. A. R., Elumalai, G. Johan, R. \& Nadzalan, A. M. (2017). Cognitive domain achievement level among Reserve Officers Training Team (PALAPES). International Journal of Academic Research in Business and Social Sciences, 7(11), 198-203.

9. DuBrin, A. J. (2015). Leadership: Research findings, practice, and skills. Nelson Education.

10. Cronin, T. E., \& Genovese, M. A. (2015). Leadership matters: Unleashing the power of paradox. Routledge.

11. Jagak, T. in Labang, R. (2016/8/6). Nembiak IPTA di nengeri tu patut diperansang nyereta unit beruniform PALAPES. Utusan Borneo, Pp. 11. http://ir.unimas.my/id/eprint/14579 
12. Ghazali N. A. in Osman R. (2015/3/21). Siswa Palapes Miliki Kelebihan. Utusan Malaysia, pp. 18. http://ddms.usim.edu.my:80/jspui/handle/123456789/7898

13. Tugong, A. (2016/8/15). Pelajar IPTA digalak sertai PALAPES. Utusan Borneo, pp. A1. http://ir.unimas.my/id/eprint/14589

14. Pierre, E., \& Oughton, J. (2007). The Affective Domain: Undiscovered Country. College Quarterly, 10(4), 1-7.

\section{How to cite this article:}

Rahmat A., Shahril M. I., Salimin N., Ahmad M. A. R. and Nadzalan A. M. The Assessment of Psychomotor Domain among Reserve Officers Training Team (PALAPES). J. Fundam. Appl. Sci. 2017, 9(6S), 1389-1397. 